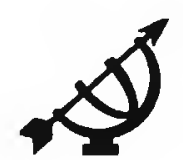

\title{
'n Verband tussen ontwikkelinge binne filosofiese hermeneutiek en ontwikkelinge in benaderings tot Bybelinterpretasie ${ }^{1}$
}

H.J.M. (Hans) van Deventer

Skool vir Basiese Wetenskappe (Vakgroep Teologie)

Potchefstroomse Universiteit vir $\mathrm{CHO}$

Vaaldriehoekkampus

VANDERBIJLPARK

E-pos: bybhjmvd@puknet puk ac.za

... even the best of writings are but a reminiscence of what we know

- Plato.

Die Interpretetion der biblischen Schriften unterliegt nicht andem Bedingungen des Verstehens als jede andere Literatur.

- Rudolf Bultmann

Abstract

A link between developments in philosophical hermeneutics and developments in opproaches to Blblical interpretation

This article relates to a discussion in Die Kerkblad (mouthpiece of the Gereformeerde Kerke in Suid-Afrika) on Biblical interpretation. First the current situation in Biblical interpretation in South Africa is sketched. Secondly, the developments in philosophical hermeneutics are outlined. In the last instance these two aspects are brought into relation with each other and a suggestion is made for a way in which these aspects could be addressed in future, especially within theological faculties with strong denominational ties.

I Hicrdie artikel is 'n uitvloeisel van navorsing wat binne die fokusarea Reformatoriese Teologie, Etiek en Samelewing in die Fakulteit Teologie (PU vir CHO) gedoen is Langs hierdie weg bedank ek graag die keurders vir die waardevolle insette wat hulle gemaak het ter verbetering van hierdie artikel Leemtes wat nog bestaan, is vir die rekening van die outeur 


\section{Inleiding}

Die lees van onlangse uitgawes van Die Kerkblad maak dit duidelik dat die verstaan of interpretasie van die Bybel 'n saak is wat leef in die harte van (sommige) kerklidmate in die GKSA. Artikels en briewe wat in hierdie publikasie verskyn het, spreek die wyse van verstaan van die Bybel vanuit verskillende gesigspunte aan (vgl. onder andere Meijer, 1998; Schulze, 1998a, 1998b; Vergeer, 1998) ${ }^{2}$. Wanneer 'n mens praat van die wyse (die hoe) van die verstaan van die Bybel (of enige objek) betree 'n mens die terrein van die hermeneutiek, die wetenskap wat die verskynsel van verstaan ondersoek.

Sommige kerklidmate sal egter by die aanhoor van hierdie woord (hermeneutiek) dadelik wou beswaar maak asof die woord " $n$ wapen in die hand van moderne teoloë" is waardeur "[h]ulle ... die waarheid en die besit daarvan (sic!) [relativeer]" (vgl. Meijer, 1998:24). Volgens Mosés Silva (1994:16), 'n welbekende Nuwe-Testamentikus binne 'n behoudende teologiese tradisie, luj die argument dikwels dat die Bybel tog duidelik is, en dat die besit van die Heilige Gees die enigste wesenlike voorwaarde vir die verstaan van die Bybel is (1 Kor. 2:10-16).

Silva (1994:16) weerlê hierdie argument wanneer hy aanvoer dat ons nie hermeneutiek benodig omdat die Bybel 'n goddelike boek is nie, maar juis omdat die Bybel ook 'n eg menslike boek is (vgl. Coetzee, 1988:22). Nader aan eie huis merk Coetzee (1988:21) op dat "[d]ie belydenis van die perspicuitas of deursigtigheid van die Skrifte nie beteken dat alles in die Skrifte klinkklaar... duidelik is nie" (kursivering van Coetzee)

Geen persoon kan met 'n beroep op die werk van die Heilige Gees beweer dat daar vir die verstaan van die Bybel nie ook gelet hoef te word op hermeneutiese teorieë nie. Die onmoontlikheid van so 'n redenasie kan duidelik gemaak word indien dieselfde redenasie toegepas word op ' $n$ ander kardinale aspek van Bybelinterpretasie, naamlik kennis van die ou tale - Hebreeus, Aramees en Grieks. Niemand in die moderne tyd het al teen die voortgaande bestudering van hierdie tale te velde getrek met 'n beroep op die duidelikheid van die Skrif of die verligtende werk van die Heilige Gees nie. Ons kan nie uit die oog verloor dat die Bybelteks hermeneutiese vertaling benodig in dieselfde mate waarin dit linguistiese vertaling benodig nie. Hierdie hermeneutiese vertaling moet kennis dra van ontwikkelinge binne die hermeneutiek, net soos wat linguistiese vertaling moet kennis dra van ontwikkelinge binne die Hebreeuse, Aramese of Griekse taalkunde (vgl. Thiselton, 1986:79). Almal wat die Bybel lees, bou -

2 Die oogmerk van huerdie artikel is nue om in direkte gesprek te tree met hierdie outeurs nie. Daarvoor sou hierdie wetenskaplike tydskrif miskien ook nie die regte forum wees nie Hierdie artike] poog om die meer prinsipiele grondslae van interpretasie te belig. Vanuit hierdie besinnung sou so 'n gesprek binne 'n ander konteks wel gepas en inderdaad nodig wees 
H.J.M. (Hans) van Deventer

bewustelik of onbewustelik - op een of ander vorm van hermeneutiese teorie. Die doel van hierdie artikel is om ontwikkelinge in die hermeneutiek na te gaan en dit in verband te bring met resente ontwikkelinge in benaderings (metodes) tot Bybelinterpretasie, veral binne die Suid-Afrikaanse konteks.

Eerstens word kortliks gelet op die huidige stand van Bybelinterpretasie in SuidAfrika. Tweedens word aandag gegee aan enkele ontwikkelinge binne die filosofiese hermeneutiek, waarna die vraag gevra word waar Bybelverklaarders staan (binne die breëre Suid-Afrikaanse konteks, sowel as die engere Gereformeerde ${ }^{3}$ konteks) wat hierdie ontwikkelinge betref

\section{Enkele ontwikkelings in Bybelinterpretasie}

Spangenberg (1994) se siening in verband met paradigmas binne die Bybelwetenskappe kan hier dien as 'n (voorlopige) ${ }^{4}$ oorsig van die huidige stand van sake in die veld van Bybelinterpretasie. Spangenberg (1994:156) maak melding van drie paradigmaverskuiwings in die Bybelwetenskappe binne die Protestantse tradisie: die verskuiwing na die hervormingsparadigma, die verskuiwing na die histories-kritiese paradigma en die verskuiwing na die literêr-kritiese paradigma.

Spangenberg gee 'n opsomming van wat onder die genoemde drie paradigmas verstaan moet word

Die hervormingsparadigma gaan van die standpunt uit dat "[d]ıe Bybel die Woord van God [is]. Deur hierdie Woord openbaar God Homself aan die gelowige mens. Die indiwiduele gelowige wat gelei word deur die Heilige Gees, kan die Bybel reg interpreteer omdat die Bybel duidelik en sy eie uitlegger is. Vir 'n korrekte uitleg is die gelowige, afgesien van die leiding van die Gees, aangewese op die histories-letterlike interpretasiewyse (Spangenberg, 1994:148, vgl. Deist, 1994a:271-275)

Die historles-kritiese paradigma word soos volg saamgevat

[d]ie Bybel is 'n versameling ou Nabye-Oosterse godsdienstige gesknfte wat deur beperkte, feilbare mense geskryf is. Verskeie van hierdie geskrifte het oor ' $n$ lang periode ontstaan en is dikwels nie net deur een outeur geskryf nie. Die geskrifte bevat die geloofsinsigte en geloofsgetuienisse van daardie mense en hul tydgenote. Hierdie mense het gedurende 'n vasomlynde tyd in die geskiedenis op aanwysbare plekke op aarde geleef. Vir 'n korrekte verstaan van die Bybel moet die leser oor grondige kennis beskik van onder andere (1) die geskiedenis van Israel en ander Ou Nabye-Oosterse volke asook die vroeë Christendom; (2) die kulturele milieu ... van daardie mense; (3) hulle

3 In hierdie artikel verwys Gereformeerd na die teologiese tradisie binne die GKSA, terwyl gereformeerd verwys na 'n breëre tradisie wat voortvloei uit die Reformasie

4 Enkele wysigings op Spangenberg se uiteensetting word later aan die hand gedoen. 
wêreldbeeld; (4) die godsdienstige oortuigings, praktyke en strominge van daardie tyd (Spangenberg, 1994:156).

Spangenberg (1994:161) som die literêr-kritiese paradigma soos volg op:

... die Bybel [word beskou] as ' $n$ versameling Ou Nabye-Oosterse godsdiensthge literatuur. Hierdie literatuur kan volgens die gangbare literatuurwetenskaplike metodes ... ontleed word. Vanweë die nuwere ontwikkeling in die literatuurwetenskap word die klem tans meer geplaas op die leser (reseptor) van die teks.

Die laaste opmerking aangaande die rol van die leser is ' $n$ belangrike aspek waarop later teruggekom word. In hierdie verband is Spangenberg in gesprek met Lategan (1984), wat paradigmaveranderings in die Bybelwetenskappe voorstel as eerstens 'n verskuiwing van die outeurspool na die tekspool, en tweedens ' $n$ verskuiwing in ondersoek van die tekspool na die leserspool. Spangenberg (1994:157) toon aan dat Lategan se model slegs van toepassing is op paradigmaverskuiwings binne die literatuurwetenskap en nie sonder meer ook op paradigmaverskuiwings in die Bybelwetenskappe nie 5 . Die feit bly egter dat die klem op die rol van die leser in die kommunikasieproses vandag ook in die Bybelwetenskappe opnuut aan die orde is (vgl. Kaiser \& Silva, 1994:240245).

Hierdie samevatting van verklaringsmodelle in die Bybelwetenskappe kan basies onder twee noemers tuisgebring word: historiese verklaringsmodelle en literêre verklaringsmodelle. Hiervolgens kan die hervormingsmodel dan getipeer word as histories-letterlik, in onderskeid van die histories-kritiese model (vgl. Deist \& Burden, 1985:98-100). Albei hierdie modelle het 'n sterk historiese inslag waarmee bedoel word dat die verklaring van die teks gekoppel word aan die bestudering van aspekte "agter" die teks, byvoorbeeld die skrywer(s), die historiese agtergrond of die ontwikkelingsgeskiedenis van die teks $^{6}$. Op hierdie punt kan voorlopig saamgevat word deur te meld dat binne die

$5 \quad$ In 'n latere en meer populêre publikasie laat Spangenberg (1998a) die duidelike onderskeid tussen die tweede en derde paradigmaverskuiwings wat in die gereformeerde teologiese tradisie waar te neem is, letwat vervaag. Hy onderskei steeds drie paradigmaveranderings (1998a 51), maar sien die tweede en derde paradigmas as begrond op 'n gemeenskaplike Skrifbeskouing. Spangenberg koppel steeds die tweede en derde paradigmas aan die opkoms van histonese kritiek en die moderne literatuurwetenskap onderskeidelik. Binne laasgenoemde paradigma (waarin Spangenberg homself posisioneer) word die Bybel beskou as "woorde oor God" en verval die goddelike komponent in die totstandkoming van die Bybel. Du Toit (1998:30) beskryf om hierdie rede Spangenberg se model in 'n populère resensie as "die einde van die teologie". Hieronder word weer na hierdie aspek verwys.

6 Daar kan aangevoer word dat wat hier beskryf word as die histories-letterlike model ook bekend staan as die grammaties-histonese model (vgl. Helberg, 1983:109-110) en dat dit wel erns maak met die teks as sodanig (vgl. "grammaties") en nie net met historiese aspekte "agter" die teks nie (vg] Deist \& Burden [1985 83-86] vir die ontwikkeling van die histories- 
Bybelwetenskappe daar vandag basies twee benaderings tot Bybelinterpretasie bestaan: historiese benaderings en literêre benaderings.

$\mathrm{Na}$ hierdie terreinsketsing word vervolgens gekyk na ontwikkelinge binne die filosofiese hermeneutiek, voordat ons terugkeer na hierdie twee benaderings tot Bybelverklaring.

\section{Enkele ontwikkelings in filosofiese hermeneutiek ${ }^{7}$}

\subsection{Schleiermacher}

Friedrich Schleiermacher (1768-1834) het 'n verandering in die siening van hermeneutiek teweeggebring. Voor Schleiermacher was die begrippe hermeneutiek en Bybelse eksegese feitlik sinoniem en het diskussie rondom hierdie begrip bestaan uit gesprekke oor metodologie (vgl. Jeanrond, 1996:282). Palmer (1969: 91) som die ontwikkeling wat Schleiermacher teweeggebring het soos volg op: “... what he [Schleiermacher] sought was not a set of rules, as earlier in hermeneutics, but a set of laws by which understanding operates - a science of understanding, which could guide the process of extracting meaning from a text".

Schleiermacher tref 'n duidelike onderskeid tussen algemene hermeneutiek (die wetenskap van die verstaan van enige geskrewe teks) en hermeneutiek as subdissipline binne die studieveld van die teologie of regte (velde waarin teksinterpretasie van belang is). Die interpretasie van vakspesifieke tekste, soos byvoorbeeld in die Bybeltekste, mag nie die algemene hermeneutiese beginsels weerspreek nie (vgl. Schlejermacher, 1986:67).

Schleiermacher was in sowel die klassieke as die teologie geskool. Vanuit hierdie agtergrond redeneer hy dat die verstaansproblematiek met betrekking tot die Bybel dieselfde is as met betrekking tot enige klassieke teks (vgl. Maraldo, 1974:23). Daarmee is die onderskeid tussen die interpretasie van die Bybel as heilige geskrif en enige ander geskrif opgehef. Die Bybel moet in elk geval eers

letterlike model vanuit die grammaties-historiese model) Hierteenoor moet opgemerk word dat wat vandag weergegee word met "grammaties", afgeles is van die Griekse tó $\gamma \rho \alpha \hat{\alpha} \mu \mu \alpha$ (to gramma) wal vertaal kan word met "letter" of "tekening" Die Latynse vertaling van hierdie Griekse selfstandige naamwoord - Latyn was die kerktaal tydens die Middeleeue - is litera, wat ook onder andere as "letter" of "skrif" vertaal kan word As bywoord (itterate) het hierdie woord in Latyn egter die betekenis van "duidelik" of "letterlik" gekry. "Grammaties" in hierdie betekenis verwys eerder na 'n letterlıke verklaring, as wat dit verwys na 'n verklaning wat ems maak met grammatika (vgl Kaiser, 1981:87-88). Binne die grammaties-historiese model moes die vak eksegese die grammatiese aspek hanteer (dikwels in die vorm van kennisname van tekskritiese notas en die verklaring van werkwoordsvorme), terwyl die vak kanoniek die historiese aspek moes bybring

$7 \quad$ Hierdie oorsig is geensins bedoel om volledig te wees nie en trek eerder 'n paar algemene lyne. 
gelees en verstaan word voordat dit as heilige geskrif herken kan word (vgl. Schleiermacher, 1986:67)

Schleiermacher het nie 'n uitvoerige en sistematiese voorstel met betrekking tot die praktiese aspek van hermeneutiek nagelaat nie. Latere navorsers het hierdie aspek gekonstrueer vanuit Schleiermacher se etiese geskrifte, sy inleiding tot die Nuwe Testament, asook die inleiding tot sy vertaling van Plato se werke (Maraldo, 1974:25). Hieruit volg dat Schleiermacher nie verstaan as onbemiddeld beskou nie. Die verstaan (van 'n teks) geskied langs 'n bepaalde weg of proses. Hierdie proses (metode) is daarop gemik om die "spreke" (of denke, selfs emosie) van die outeur in die "spreke" van die interpreteerder te rekonstrueer (Maraldo, 1974:124, vgl. ook Lundin, 1991:154). In wese moes die kloof tussen die huidige interpreteerder en die destydse outeur oorbrug word deur die self te verplaas na die lewens- en denkraamwerk van die destydse outeur (vgl. Schleiermacher, 1986:113). Die subjek-objekproblematiek word dus hanteer deur die subjek te verplaas na die raamwerk van die skepper van die objek. Palmer (1969:93) spreek op hierdie punt kritiek uit teen Schleiermacher se projek. Deur as vertrekpunt te neem dat die doel van hermeneutiek die rekonstruksie van die denkproses van die outeur is, verskuif Schleiermacher die klem weg van die inhoud (matter) van die teks, na 'n vae innerlike denkproses ${ }^{8}$.

\subsection{Dilthey}

Wilhelm Dilthey (1833-1911) is waarskynlik die bekendste volgeling van Schleiermacher (vgl. Jeanrond, 1996:282). Dilthey se vertrekpunt was om, soos wat Kant vir die natuurwetenskappe gedoen het, 'n redelike begronding vir die geesteswetenskappe daar te stel $^{9}$ (Maraldo, 1974:67). In hierdie strewe identifiseer Dilthey hermeneutiek as 'n grondliggende dissipline van alle geesteswetenskappe (vgl. Dilthey, 1989:165-169). Terwyl Schleiermacher se hermeneutiek op die verstaan van geskrewe tekste berus het, het Dilthey se hermeneutiek die verstaan van alle menslike ervaring ten doel gehad (Jeanrond, 1996:282, vgl. Palmer, 1969:114).

Maraldo (1974:70) som Dilthey se siening van hermeneutiek soos volg op: "In ihrer Fülle stellt die Hermeneutik die überlieferten Regeln und Methoden dar, die zum allgemeingultigen Wissen der geistigen Welt hinzuftihren vermogen" (my kursivering - HJMvD).

8 Alhoewel hierdie kritiek van Palmer gereguerdig is, moet onthou word dat Schleiermacher 'n kind van sy tyd was en dat hierdie strewe van hom (om deur te dring na die emosie "agter" die teks) begrond is in die denke van die Romantiek (vgl. Thiselton, 1992:209-211)

9 Anders as Kant wil Dilthey nie werk met die Kantiaanse abstraksie "denkende subjek" nie, maar met 'n vlees-en-bloed histories-bepaalde subjek (vgl. Thiselton, 1992 249) 
Die verstaansmetodiek behels die subjektiewe herbelewing (nacherleben) van objektiewe gebeure ${ }^{10}$. Die skakel tussen hierdie subjektiewe en objektiewe pole is die menslike lewe self (vgl. Maraldo, 1974:125). Milbank (1994:264) beskryf hierdie skakel as "an essential ontological identity between the object studied and the person studying". Die gevolg van die interpretasiehandeling is dat die interpreteerder gelei word na selfontdekking. Die gedagte dat dieselfde belewing deur 'n latere interpreteerder daarvan "herleef" en dan beskryf kan word, ontkom nie aan ' $\mathrm{n}$ vorm van positivisme wat reeds by Schleiermacher merkbaar was nie, alhoewel Dilthey groter klem plaas op die kontekstualiteit van betekenis $^{11}$ (vgl. Palmer, 1969:118-119).

Hierdie siening aangaande interpretasie het nie na Dilthey tot 'n einde gekom nie, alhoewel Heidegger en veral Gadamer in reaksie gekom het teen hierdie vorm van "objektiewe verstaan". Palmer (1969:57) wys daarop dat die Italiaanse regshistorikus Betti 'n meer kontemporêre eksponent van hierdie gedagterigting is. Palmer som Betti se siening soos volg op:

For Betti, the interpretive object is an objectification of man's spirit (Geist) expressed in sensible form. Interpretation, then, is necessarily a recognition and reconstruction of the meaning that its author, using a special kind of unity of materials, was able to embody. This means, of course, that the observer must be translated into a foreign subjectivity and, through an inversion of the creative process, get back the idea or 'interpretation' which is embodied in the object.

Betti onderskei dan vier "momente" in die interpretasieproses. Hierdie momente kom baie naby aan 'n metode vir interpretasie (vgl. Thiselton, 1992:253).

Schleiermacher en Dilthey is verteenwoordigers van 'n meer realistiese perspektief op die werklikheid. 'n Volgende ontwikkelingsfase in filosofiese hermeneutiek verteenwoordig 'n meer fenomenologiese perspektief op die werklikheid (vgl. Palmer, 1969:60).

10 Palmer (1969:109) haal Dilthey aan waar laasgenoemde belewing beskryf as 'n kategorie wat die subjek-/ objek-onderskeiding voorafgaan: "the expenence [Erlebnis - HJMvD] does not stand like an object over against its experiencer, but rather its very existence for me is undifferenciated from the whatress which is present for me in it" (vgl. Dilthey, 1989:246, 252$253,262-263)$

11 Thiselton (1992:250) wys ook die invloed van die Romantiek op Dilthey - 'n invloed wat gesetel is in die gedagte dat tekste as lewensuitdrukkinge beskou kan word en as depositos van die ervaring van "lewe". Hierdie objektiverings van ervaring (tekste) dien nou as invalshoek vir die interpreteerder wat betekenis agter hierdie tekste ontdek 


\subsection{Heidegger}

Martin Heidegger (1889-1976) hoort (wat chronologie en denke betref) tuis tussen die name van Dilthey en Gadamer (die volgende persoon onder diskussie) ${ }^{12}$. Hy het gebreek met die fenomenologiese filosofiese skool van sy tyd. Volgens Husserl, een van die groot eksponente van hierdie denkrigting en leermeester van Heidegger, is dit die taak van die filosofie om fenomene in die bewussyn te beskryf ${ }^{13}$. 'n Fenomeen is 'n beskrywing vir die wyse waarop objekte hulself deur hulle voorkomste presenteer (Sahakian, 1968:330). Die doel van fenomenologie sou dan wees om die wese van 'n objek te ontdek. Heidegger verskuif die klem weg van die kenteoretiese na die ontologiese - die mens kan iets slegs ken, omdat dit bestaan en sigself manifesteer (Milbank, 1994:297).

Heidegger se gebruik van die woord hermeneutiek verskil van dié van Schleiermacher en Dilthey, omdat Heidegger dit gebruik in die sin van 'n primêre handeling van interpretasie waardeur 'n fenomeen uit die verborgene aan die lig gebring word. Palmer (1969:130) vat hierdie gebruik van hermeneutiek soos volg saam: “... hermeneutics becomes an ontology of understanding and interpretation". Heidegger transendeer die hele subjekobjekdilemma by interpretasie deur verstaan en interpretasie meer grondliggend te plaas as deel van die veronderstelde en onopmerklike "wêreld" waarin die mens hom-/haarself bevind. Hermeneutiek in hierdie sin veronderstel dus iets veel meer grondliggend as teksinterpretasie. Wanneer dit kom by teksinterpretasie is die doel nie om te sê wat die outeur gesê het nie, maar "interpretation must be creatively open to the as yet unsaid" (Palmer, 1969:147). Daarom is interpretasie ' $n$ herontdekking van die oorspronklike gebeure van die "aan-die-lig-kom" van 'n fenomeen uit die verborgene (vgl. Palmer, 1969:157$158)$.

Dit was veral Heidegger se uitwys van die rol van vooronderstellings in die interpretasiehandeling wat van belang is vir Bybelinterpretasie. Thisleton (1992:280) vat Heidegger se gedagte rondom die idee dat interpretasie nooit vooronderstellingloos is nie, soos volg saam: "We 'project' forward certain anticipations which will make sense of the phenomenon to be understood".

I2 Palmer (1969:55) wys daarop dat Emslio Betti vir Heidegger daarvan beskuldig het dat hy ne meer deel vorm van die groot tradisiestroom wat sedert Schleiermacher via Dilthey en andere die ontwikkelingslyn in die metodologie van interpretasie verteenwoordig nie

13 Heidegger kom met sy vorm van fenomenologie juis in opstand teen Husserl se herleiding van fenomene na die transendente subjektiwiteit van die menslike bewussyn (vgl. Palmer, 1969 (25) 
H.J.M. (Hans) van Deventer

Heidegger se eksistensiële hermeneutiek het verder 'n groot invloed gehad op die Nuwe-Testamentikus, Bultmann (vgl. Palmer, 1969:48-52)14. Bultmann het aangevoer dat die daad van Bybelverstaan 'n daad van eskatologiese beslissing vir die ware Christelike lewe moes wees ${ }^{15}$. Sy program van demitologisering was daarom daarop gemik om daardie dele van die Bybel wat 'n wêreldbeskouing van ' $n$ vergange tyd reflekteer te vertaal binne 'n moderne konteks waarin dit die selfverstaan van die moderne mens sou uitdaag tot 'n beslissing (Jeanrond, 1996:284).

\subsection{Gadamer}

Hierbo is daarop gewys hoe Schleiermacher en Dilthey onder andere verwys na die gebruik van die regte metode (proses) om sodoende die gaping tussen die objek en die interpreteerder op te hef, sodat die interpreteerder inskakel by die konteks van die objek - alhoewel hierdie strewe by Dilthey meer genuanseerd is as by Schleiermacher. Hierdie ontkenning van die waarde van die huidige konteks in die interpretasiehandeling is deur Hans-Georg Gadamer (1900- ) gekritiseer (vgl. Gadamer, 1975:244, 246, 264). Die titel van Gadamer se bekende werk Wahrheit und Methode is volgens Palmer (1969:163) ironies bedoel: metode is juis nie die weg na waarheid nie.

Palmer (1969:164) toon aan dat Gadamer in sy denke anti-rasionalisties is. Hy wil juis wegkom van die menslike rede as die finale verwysingspunt vir menslike kennis. Daarom kies hy vir 'n meer dialektiese model waardeur kennis nie "'n iets" is wat deur "'n iemand" bekom word nie, maar iets is waarby iemand selt betrokke is. Gadamer beklemtoon dat die eie konteks van die interpreteerder (waarvan hy/sy nie kan ontkom nie) deel vorm van die hermeneutiese proses. Die mens se "geplaas-wees" in die wêreld kan nie ongedaan gemaak word deur 'n wetenskaplike metode nie (Thiseiton, 1992: 320). Interpretasie is dus nie bloot die reproduksie van 'n betekenis uit die verlede nie, maar 'n produksie van betekenis wat verlede en hede omvat en verdiskonteer (vgl. Gadamer, 1975:264). In Gadamer (1975:273) se woorde: "Understanding ... is always the fusion of (the past and present) horizons which we imagine to exit by themselves".

Interpretasie is 'n gebeure wat plaasvind wanneer die huidige horison van die interpreteerder (wat insluit alle [historiese] vooronderstellings en invloede - 'n

14 Karl Barth het kritiek uitgespreek teen die bestudering van die filosofiese vooronderstellings van Bybelinterpretasie, alhoewel hy en Bultmann saamgestem het dat Bybelinterpretasie meer is as die historiese en grammatiese ontleding van Bybeltekste (vgl. Jeanrond, 1996:284).

15 Heidegger het krities gestaan teenoor die neo-Platonistiese gedagte om "wese" (being) vas te vang in 'n statiese idee. Dit sou in die Westerse denke daaroe lei dat waarheid nie gefundeer is in bestaan nie, maar in die waarneming van 'n idee (vgl. Palmer, 1969:143). 
mens kan ook daarna verwys as "die tradisie") en die historiese horison van die "objek" saamvloei "[to] constitute the one great horizon that moves from within and, beyond the frontiers of the present, embraces the historical depths of our self-consciousness ... [i]t is, in fact, a single horizon that embraces everything contained in historical consciousness" (Gadamer, 1975:271). Die temporele kloof tussen interpreteerder en geïnterpreteerde vorm die basis van verstaan eerder as wat dit 'n negatiewe faktor is wat deur 'n oorbrugging (deur middel van 'n "objektiewe" verplasing na die verlede) opgehef moet word. Linge (1976:xiv) som dit soos volg op: "[o]ur prejudices do not cut us off from the past, but initially open it up to us".

Die rol wat vooronderstellings in die wetenskap speel, is geensins 'n vreemde gedagte binne die Reformatoriese filosofie nie (vgl. Wolterstorff, 1984:63-70). Die volle konsekwensie van hierdie siening is egter nie in die Reformatoriese teologie altyd verdiskonteer nie. Palmer (1969:183) som hierdie konsekwensie soos volg op: "If there can be no presuppositionless interpretation, then the notion of one 'right interpretation' as right in itself is a thoughtless ideal and an impossibility. There is no interpretation without relationship to the present, and this is never permanent and fixed".

Die huidige horison word voortdurend gevorm deurdat ons al ons vooronderstellings toets aan die hand van die tradisie waaruit ons kom. Gadamer $(1975: 273)$ stel dit soos volg: "[h]ence the horizon of the present cannot be formed without the past. There is no more an isolated horizon of the present than there are historical horizons". Die onderskeiding tussen hierdie twee horisonne is egter noodsaaklik, omdat die spanning tussen die hede en die verlede nie bloot deur naïewe assimilasie van die horisonne opgehef kan word nie, maar die hermeneutiese taak is juis afgestem op die blootlê van hierdie spanning. In die hermeneutiese proses dra die verskillende huidige horisonne van verskillende interpreteerders daartoe by dat verskillende betekenismoontlikhede van die teks oopgaan. Daarom is verskillende interpretasies van dieselfde teks moontlik.

Gadamer (1975:330, 345-351) gebruik 'n gespreksmetafoor om sy verstaan van interpretasie mee te verduidelik. Die interpreteerder en die objek word as gelyke gespreksgenote beskou. Die gespreksvoering is nie die prerogatief van die interpreteerder nie. Albei gespreksgenote neem by wyse van wedersydse vrae aan mekaar deel aan hierdie gespreksproses. Gadamer (1975:330) meld: "To conduct a conversation means to allow oneself to be conducted by the object to which the partners in the conversation are directed".

Hierdie gesprek vra van die interpreteerder om nie sy vooronderstellings op die teks af te forseer nie, maar om hierdie vooronderstellings op die spel te plaas deur dit deur die teks te laat bevraagteken (vgl. Weinsheimer, 1985:208, Palmer, $1969: 168$ ). Die wese van hierdie gesprek is dat dit 'n voortgaande entiteit is wat onafhanklik van die interpreteerder en objek is (vgl. Gadamer, 1975:345). Dit is 
baie belangrik dat hierdie gesprek ' $n$ oop gesprek is waarin toegelaat word dat die eie opinie bevraagteken word. Die gesprek bestaan dus uit die kuns van vraagstelling sonder om die ander gespreksgenoot te uitoorlê, en is gerig op die objek waarop albei gespreksgenote fokus (vgl. Gadamer, 1975:330). Die gesprek is nie oop in die sin dat die gespreksgenote kan sê wat hulle wil nie, want dan word die gesprek gesaboteer. Gesprek is die proses van konsepvorming om uit te kom by wedersydse verstaan en die bereik van 'n gesamentlike betekenis (Weinsheimer, 1985:211, vgl. Gadamer, 1975:349) Hierdie gesamentlik betekenis is nie 'n wedersydse doel wat as onafhanklike entiteit bestaan reeds voor die gesprek nie, maar word as 't ware in die wedersydse verstaan "geskep". Taal vorm uiteindelik die universiele medium waarin verstaan gerealiseer word - tot so 'n mate dat "the preferred object of interpretation is a linguistic one" (Gadamer, 1975:351).

Hierdie ietwat langer oorsig van die werk van Gadamer is daarop gerig om aan te dui waar die huidige gesprek in filosofiese hermeneutiek rondom die verstaansproses min of meer staan. Dit is duidelik dat enige vorm van objektiewe verstaan binne hierdie model nie houdbaar is nie en dat erns gemaak moet word met die rol (en vooronderstellings) van die interpreteerder ${ }^{16}$.

\section{Bybelinterpretasie en filosofiese hermeneutiek - waar staan Bybelverklaarders?}

\subsection{Die belang van nadenke oor hermeneutiese aangeleenthede}

Nadat daar tot dusver gewys is op twee onderskeibare benaderings tot Bybelinterpretasie (t.w. histories en literêr) en verder 'n oorsig gegee is van ontwikkelinge binne die filosofiese hermeneutiek, word hierdie twee sake onder die huidige hoof met mekaar in verband gebring.

Alvorens dit gedoen word, word weereers aandag gegee aan die meer prinsipiële saak waarna in die inleiding verwys is, naamlik waarom moet hierdie sake hoegenaamd met mekaar in verband gebring word? Die vraag na hoe 'n mens verstaan, met ander woorde watter prosesse verstaan as verskynsel beïnvloed, moet altyd op die agenda van Bybelverklaarders wees. Insigte in hierdie prosesse is nie staties nie, maar dinamies en ontwikkel soos wat elke nuwe

n Ander model warvolgens betekenis in die tweede helfte van die twintigste beskryf is en waarbinne die interpreteerder of interpreterende gemeenskap " $n$ rol speel, is die van Paul Ricoeur Daarvolgens beskik " $n$ geskrewe teks or ' $n$ "surplus van betekenis" wat ontdek word deur opeenvolgende gemeenskappe wat die teks binne hulle omstandighede lees, sonder om hulle te verplaas na of selfs volledig kennis te dra van die omstandighede wat vir die corspronklike lesersgemeenskap gegeld het 
geslag navorsers oor die verstaansproblematiek nadink. Waar hierdie nadenke ontbreek, stol die interpretasieproses en weinig ruimte word gelaat vir nuwe insigte (vgl. Deist, 1994a:274). Indien die oopdekking van nuwe kennisvelde van die agenda van Bybelverklaarders verbonde aan universiteite verdwyn, verdwyn daarmee saam die moontlikheid om aan hierdie instellings verbonde te bly.

Die vraag wat nou beantwoord moet word, is tot watter mate Bybelwetenskaplikes kennis geneem het van die ontwikkeling in die filosofiese hermeneutiek weg van die idee dat die navolg van 'n "korrekte" metode die kloof tussen subjek en objek oorbrug en lei tot die korrekte interpretasie (soos vergestalt in die denke van Schleiermacher en Dilthey). In die beantwoording van hierdie vraag sal die saak rondom bestaande paradigmaverskuiwings in die Bybelwetenskappe ook weer aan die orde kom. Die gestelde vraag word eers behandel aan die hand van enkele voorbeelde vanuit die geledere van Bybelwetenskaplikes binne die breëre Suid-Afrikaanse konteks.

\subsection{Paradigmaveranderings binne historiese konteks}

Gedurende die laat-sewentiger- en die tagtigerjare is die gemeenskap van Bybelwetenskaplikes in Suid-Afrika gekenmerk deur debatte rondom Bybelverklaring, sowel as die filosofiese onderbou waarop Bybelverklaring(s) rus (vgl. onder andere die kritiek van Van Aarde [1981] op onder andere Schulze [1980]; die gesprekke tussen Lion-Cachet [1984] en Deist [1984]; Deist [1988] se opmerkings aangaande Bybelverstaan in die NGK gedurende die dertiger- en veertigerjare17; en laastens die gesprek tussen Snyman [1992a, 1992b] en Vergeer [1993] in die vroeë negentigerjare).

Hierdie debatte het veral betrekking gehad op die historiese benadering tot Bybelinterpretasie en die grondslae van hierdie benadering. Hierbo is gewys op twee komponente binne hierdie benadering, naamlik die histories-letterlike en die histories-kritiese komponente (vgl. Deist \& Burden [1985:83-113] vir 'n vollediger uitwerk van hierdie onderskeid). Simplisties gestel, het die verskil tussen hierdie komponente daarin gelê dat, alhoewel albei belangstel in iets "agter" die teks met die oog op die interpretasie van die teks, paaie uiteengegaan het oor hoe (vertrekpunte en metodes) daardie gegewens "agter" die teks bekom word.

17 Alhoewel Deist verwys na gebeure tydens die eerste helfte van hicrdie eeu, moet hy gelees word teen die agtergrond dat'n rungskommıssie van die NG Kerk in die middel sewentigerjare ondersoek ingestel het na aspekte van sy leer, op grond van sy openlike breuk met die tradisionele opvatting aangaande Bybelverklaring (vgl. Spangenberg, 1998b:540-541) 
Die histories-letterlike komponent het met 'n objektiewe taal- en geskiedenisbeskouing, wat begrond is in die filosofiese tradisie bekend as common sense realism, blont geponeer dat "soos dit daar staan, het dit gebeur" (vgl. die kritiek van Deist [1988:25] teen hierdie opvatting). In navolging van die Baltimoreskool in die VSA is argeologiese "bewyse" in hierdie kring ook soms aangevoer ter wetenskaplike "stawing" van die Ou-Testamentiese beskrywing van 'n gebeurtenis" 18 . Hierdie positiewe siening van die belang van "Bybelse argeologie" het vinnig vervaag namate argeologiese vondste die Bybelse weergawe van gebeure begin weerspreek het. 'n Sprekende voorbeeld is die feit dat kennis geneem is van die werk van Kenyon by Jerigo waardeur die "argeologiese bewyse" wat Garstang twintig jaar tevore (1930-1936) gevind het vir die Israelitiese verwoesting van die stad in die vroeg 15 de eeu v.C., as foutief bewys is (vgl. Kenyon, 1978:33-40). Die ondertone van 'n Baltimorebenadering kan egter nog gehoor word in Prinsloo (1977:100) se opmerking dat weens 'n gebrek aan inligting "ons dus nie van argeologie gebruik kan maak om die val van Jerigo wetenskaplik te bewys of te ontken nie". Lion-Cachet (1989:43) is meer skepties oor die rol van argeologie en merk rondom Kenyon se bevindings oor die val van Jerigo op dat "die argeologiese wetenskap ... op ander plekke met hulle bevindings gefouteer [het]". Waar argeologie die Bybel dus weerspreek, is die moontlikheid van foutiewe argeologiese (!) aannames nie uit te sluit nie

Teenoor die histories-letterlike komponent het die histories-kritiese komponent erns gemaak met ontwikkelinge in die geskiedkundige vakwetenskap (historiografie). Die metodes en resultate wat vir algemene histories-literêre werke en beskrywings gegeld het, is ook op die Ou-Testamentiese beskrywings van toepassing gemaak (Deist, 1987:32-34, 39). Die botsing tussen die historiesletterlike en histories-kritiese komponente het binne kerklike kringe in die middel-sewentigerjare aanleiding gegee tot ringondersoeke binne die NG Kerk na die leer van F.E. Deist en W.S. Vorster (vgl. Spangenberg, 1998b:540-546). Hierdie botsing is ook gereflekteer binne die geledere van akademiese vakverenigings.

Sedert die sewentigerjare het daar ook 'n ontwikkeling binne die internasionale Bybelwetenskaplike gemeenskap plaasgevind. Daar het 'n kentering gekom in die invloed van die histories-kritiese metodes binne die Bybelwetenskappe. Hierdie kentering het saamgehang met die besef dat die objektiewe rekonstruksie van gebeure ' $n$ onhaalbare (posivitiese) ideaal is. Terselfdertyd het daar (na aanleiding van ontwikkelinge binne die algemene literatuurwetenskap, byvoorbeeld die opkoms van New Criticism) groter belangstelling gekom in die betekenis van die teks as geslote sisteem, onafhanklik van die historiese milieu

18 Deist (1988:23) haal in hierdie verband Venter (1939:125-126) aan 
waarin dit ontstaan het (vgl. Barton, 1996:2; Clines \& Exum, 1993:11-12). Op die gebied van die Bybelwetenskappe binne die internasionale arena (waar die histories-letterlike versus histories-kritiese debat reeds tussen 50 en 100 jaar tevore grootliks uitgewoed is [vgl. Deist, 1994a:68-70, 97-98]) het navorsers begin om hierdie nuwe metodes vanuit die algemene literêre wetenskap ook op die Bybelteks van toepassing te maak.

Plaaslik is die literêr-kritiese paradigma ook gunstig ontvang - volgens Deist (1994a:293-294, 1994b:166) veral in daardie kringe waar die histories-kritiese metodes vroeër afgewys is. Hierdie skuif weg van die historiese (en veral histories-letterlike) na die literêr-kritiese benadering het egter nie die plaaslike debat laat taan nie; inteendeel - die felheid daarvan het toegeneem. As rede hiervoor kan aangevoer word dat meer behoudende teoloë in 'n literêre benadering ' $n$ intemasionaal erkende metodologie gesien het waarbinne hulle kon werk, sonder om die vrae wat die historiese-kritiese skool al die tyd aan die histories-letterlike skool gestel het, te beantwoord (vgl. Van Aarde [1981:11 se kritiek op Coetzee en Floor). Inteendeel, hierdie vrae sou nie meer op die literêrkritiese agenda wees nie (Deist, 1994a:290). (Teoloë wat die histories-kritiese benadering voorgestaan het, was meestal verbonde aan kerklik-onafhanklike fakulteite, soos aan Unisa.)

Teen hierdie agtergrond skryf prof. Jurie le Roux (toe verbonde aan UP, na 'n lang verbintenis met Unisa) in opdrag van die Ou-Testamentiese Werkgemeenskap van Suid-Afrika 'n resente geskiedenis van Ou-Testamentiese navorsing in SA (vgl. Le Roux, 1993) waarin die periode 1957-1987 in oënskou geneem is. Die werk dra die insiggewende titel "A story of two ways". Die "twee weë" waama verwys word, is die histories-kritiese en literêr-kritiese weë. Hierdie werk heg oor die algemeen meer waarde aan die histories-kritiese "weg" en is uit verskillende oorde gekritiseer (soms met vlymskerp kritiek, vgl. Loader, 1994)

In hierdie werk van Le Roux figureer teoloë vanuit die Gereformeerde tradisie nie sterk nie. Wanneer daar na hulle bydraes verwys word, is dit in die konteks van die verwerping van die histories-kritiese benadering (in die geval van J.H. Kroeze) en die voorstaan van 'n teksimmanente (strukturele) benadering (in die geval van H.F. van Rooy) (vgl. Le Roux, 1993:195-197, 343).

Die debat tussen die historiese en literêre benaderings het momentum gekry toe voorstanders van die onderskeie benaderings die vooronderstellings van die "ander" benadering probeer ontbloot het. In 'n sekere sin het hierdie debat 'n resente kulminasiepunt bereik in 'n gesprek tussen Le Roux (1996) (vanuit 'n historiese hoek) en Prinsloo (1996) (vanuit 'n literêre hoek) waarin daar sonder skroom kritiek gelewer is op (onder andere) die vooronderstellings van die "ander" benadering. 
Le Roux het in sy artikel beklemtoon dat die positivistiese ideaal van objektiewe wetenskapsbeoefening nie haalbaar is nie. Hy toon dit aan met verwysing na die model van Gadamer ${ }^{19}$, wat van toepassing gemaak word op sy siening van teksimmanente eksegese. Op sterkte van hierdie toepassing word die literêrkritiese model geteken as 'n positivistiese projek. Dit is egter opvallend dat dieselfde tipe kritiek ook al teen die histories-kritiese benadering ingebring is. Nations (1983:6) beskyf die grondslag van hierdie benadering soos volg: “... criticism must be freed from dogmatic presuppositions, maintain a high degree of objectivity, enshew ecclesiastical controls, and accept secular historians' notions of historical homogeneity, of cause and effect relationships and of the criticism of sources" (my beklemtoning) ${ }^{20}$. Die soortgelyke kritiek wat op albei hierdie benaderings van toepassing gemaak kan word, word hieronder verder bespreek wanneer die bestaande paradigmas binne die Bybelwetenskappe heroorweeg word.

\subsection{Bestaande paradigmas in Bybelverklaring heroonweeg}

Hierdie bespreking van die stand van Bybelverklaring in Suid-Afrika en die ontwikkeling binne die filosofiese hermeneutiek laat egter 'n vraag ontstaan na die aanvanklike beskrywing van die huidige toestand binne die Suid-Afrikaanse konteks. Hou die paradigmaveranderinge wat Spangenberg skets, bloot verband met 'n gewysigde fokus op die teks, naamlik op óf historiese óf literêre aspekte en verbandhoudende verklaringsmetodes? Hieronder word 'n voorstel met betrekking tot die sketsing van die terrein binne 'n Suid-Afrikaanse konteks aan die hand gedoen.

Eerstens word gemeen dat die gedagte van drie paradigmaverskuiwings heroorweeg moet word. Alhoewel Spangenberg aanvoel dat die tweede (historiese) en derde (literêre) paradigmas nie so ver van mekaar verwyder is nie, onderskei hy dit steeds. Daar word gemeen dat eerder van twee paradigmaverskuiwings in die Bybelwetenskappe gepraat moet word. Hierdie twee verskuiwinge hou nie verband met Lategan se voorstel dat dit gekoppel moet word aan (1) die verskuiwing van belangstelling in die outeurspool na belangstelling in die tekspool en (2) die verskuiwing van belangstelling in die tekspool na die leserspool nie.

19 In die streng sin van die woord kan nue van Gadamer se "model" gepraat word nie, omdat hy nie 'n model vir interpretasie daarstel nie, maar eerder beskryf wat dit is wat tydens interpretasie plaasvind (vgl Gadamer, 1975:263)

20 In 'n meer resente werk maak Dobbs-Allsopp (1999-271) ook melding van die "objectivist and foundationalist assumptions which have informed and motivated historical-critical practices in the past". 
Lategan se voorstel hou meer verband met wesenskenmerke van 'n teks ${ }^{21}$ wat tydens teksinterpretasie op die voorgrond kom, terwyl Spangenberg meer fokus op die gebruik van bepaalde verklaringsmetodes. Die drie paradigmas wat hier voorgestel word, het egter 'n baie meer fundamentele onderskeid, naamlik in kenteoretiese vertrekpunt. Die drie paradigmas kan getipeer word as 'n premodernistiese paradigma, 'n modernistiese paradigma en 'n postmodernistiese paradigma. Ter wille van ruimte kan die volgende opsomming van hierdie paradigmas weergegee word, gevolg deur 'n kort verklaring:

\begin{tabular}{|c|c|c|c|}
\hline & $\begin{array}{c}\text { Pre-modernistiese } \\
\text { paradigma }\end{array}$ & $\begin{array}{l}\text { Modernistiese } \\
\text { paradigma }\end{array}$ & $\begin{array}{l}\text { Postmodernis- } \\
\text { tiese paradigma }\end{array}$ \\
\hline $\begin{array}{l}\text { Kenteoretiese } \\
\text { vertrekpunt }\end{array}$ & $\begin{array}{l}\text { Wat deur die tradt- } \\
\text { sie as (geopenbaar- } \\
\text { de) waarheid aan- } \\
\text { vaar is, is waar. }\end{array}$ & $\begin{array}{l}\text { Wat deur weten- } \\
\text { skaplike metodes } \\
\text { as waar bewys is, } \\
\text { is waar. }\end{array}$ & $\begin{array}{l}\text { Absolute waarheid } \\
\text { is nie bereikbaar } \\
\text { nie - wat waar is, } \\
\text { is relatief. }\end{array}$ \\
\hline
\end{tabular}

Binne elkeen van hierdie paradigmas is alle wesensfasette van die teks (outeur, teks en leser) in oenskou geneem, alhoewel sommige fasette gedurende verskillende periodes dalk meer aandag ontvang het.

Daar word byvoorbeeld in die pre-modernistiese paradigma (wat vandag steeds in sommige kringe in swang is ${ }^{22}$ ) wel gelet op die outeurspool (die hele histories-letterlike omgang met die teks waarin die klem val op die outeur en sy historiese konteks [vgl. McCartney \& Clayton, 1994:112] kan hier as verwysing dien). Die bestudering van die tekspool kom in meer resente publikasies veral aan die orde in die gebruik van gedagtestruktuurontleding (vgl. Coetzee, 1988:19-37). Lowth (1969) se beskrywing van die poëtika van die Psalms is 'n meer klassieke voorbeeld van die fokus binne die pre-modernistiese paradigma, wat op die tekspool geplaas word. Wat aandag aan die leserspool binne hierdie paradigma betref, vind ons 'n besondere vertakking binne die leser-responsbenadering ${ }^{23}$, naamlik die evaluering van vorige lesers se lesings van die teks,

21 Naamlik dat 'n teks 'n outeur het. 'n tcks is en deur 'n leser gelecs word

22 Snyman (1992a) het aangetoon dat die Teologiese Skool van Potchefstroom een van hierdie "knnge" verteenwoordig. Van Rooy (1995:60) het egter daarop gewys dat Snyman me die meer resente werke van teoloe verbondc aan hierdie instelling in ag geneem het nie.

23 Fowler (1992:378) wys daarop dat daar binne die leser-responsrigting nie eenstemmigheid bestaan oor die spesifieke fokus van hierdue soort studies nie. Die vertakking waarna hier verwys word, word beskryf as die "'objectifying' pole". Dit wat "ge-objektiveer" word is "the experience of reading within a tradition of criticism" (Fowler, 1992:378-379). Hierdie studies fokus op die wyse waarop die teks deur verskillende kntiese gemeenskappe gelees en beoordeel is 
maar dan vanuit 'n sterk polemiese hoek (hier kan verwys word na onder andere Hieronymus se kommentaar op die boek Daniel waarin die lesing van Porphyrius skerp afgewys word [vgl. Hieronymus, 1958:15]).

Die negatiewe sentiment teenoor die modernistiese paradigma uit hierdie kringe blyk uit Le Roux se bespreking van die kritiek wat Kroeze op Gunkel se verklaring van die Psalms het. Le Roux (1993:270-271) toon aan dat Kroeze beswaar maak teen Gunkel se literêre ${ }^{24}$ en historiese benadering (vgl. Kroeze, 1963:42, 43). Albei hierdie aspekte van vormkritiek toon trekke van 'n modernistiese kenteoretiese vertrekpunt. So meld Tucker (1971:1) in sy bespreking van vormkritiek: "[b]ecause the Old Testament is literature, literary methods must be used in order to understand it" (my beklemtoning). Die historiese aspek word beklemtoon wanneer Tucker (1971:1) verder meld: "[a]ny attempt to understand the Old Testament which does not begin with a knowledge of what its various parts meant in and to the life of that people is therefore destined to be incomplete and perhaps even false" (my beklemtoning).

Binne die modernistiese paradigma is die kenmerk die kritiese omgang met die teks - krities in die sin van wetenskaplik-ontledend. Die teks is deur middel van objektiewe metodes uit óf die historiese wetenskap óf die literêre wetenskap ontleed en verklaar. Die outeurspool (die sosio-historiese milieu van die skrywer(s), samesteller(s), redaktor(s) asook die bronne tot hulle beskikking) is in (dikwels baie fyn) besonderhede beskryf, dikwels met behulp van insigte vanuit die historiese wetenskap. Binne hierdie paradigma het fokus op die tekspool die vorm angeneem van gedetaileerde ontledings van strukture en allerlei literêre tegnieke25. Die leserspool is effens afgeskeep binne hierdie paradigma (moontlik juis vanweë die fokus op wetenskaplike "objektiwiteit"). Hierdie aspek van teksstudie het ook die vorm aangeneem van kritiese diskussies met tekste van lede wat die pre-modernistiese paradigma verteenwoordig (hierbo is na enkele van hierdie diskussies verwys).

Binne die postmodernistiese paradigma val die klem op die aanvaarde vertrekpunt dat die verstaan van 'n teks onlosmaaklik verbind is aan die subjektiwiteit van die leser (vgl die bespreking van Gadamer hierbo). Binne hierdie paradigma word historiese vrae rondom die outeurspool steeds betrek, maar dan vanuit die konteks van die Neo-Historisme (vgl. Postmodern Bible [PMB], 1995:146-147; Veeser, 1994). Die fokus op die tekspool word betrek deurdat metodes vanuit die poststrukturalisme en dekonstruksie ook op die

24 Kroeze (1963:42) meld in hierdie verband: "Gunkel is considering the psalm (sic) as mere literary phenomena [and therefore] he misses the whole point".

25 Die studie van Le Roux (1993) bied 'n oorsig van die werk wat vanuit 'n Suid-Afrikaanse raamwerk binne die modemistiese paradigma gedoen is en wat verband hou met sowel die outeurs-as die tekspool 
Bybel van toepassing gemaak word (vgl. PMB, 1995:119-148, Clines, 1993). Die grootste impak vanuit hierdie paradigma is egter op die terrein van die leserspool. Hierin word "betrokke" lesings van die teks vanuit voorafingenome vertrekpunte (bv. 'n feministiese perspektief) aangebied. Die klem val hier juis op subjektiwiteit (vgl. PMB, 1994:225-271; Exum, 1993).

Indien hierdie gewysigde uiteensetting rondom bestaande paradigmas in die Bybelwetenskappe aanvaar word, dan blyk dit dat sowel die historiese as die literêre benaderings in Suid-Afrika steeds hoofsaaklik werk met 'n hermeneutiese model waarvolgens baie klem geplaas word op die objektiewe verstaan van 'n teks en die gebruik van die regte metode(s) (ala Schleiermacher en Dilthey) om by daardie verstaan uit te kom (Punt [1998] het onlangs hierna verwys as "methodolomania"). Alhoewel die tekortkominge verbonde aan hierdie model erken word ${ }^{\mathbf{2 6}}$, is Bybelwetenskaplikes wat verbonde is aan teologiese fakulteite met 'n denominasionele inslag nog sku om die paradigmaverskuiwing tussen die tweede en derde paradigmas in hulle werk te voltrek ${ }^{27}$. Die rede daarvoor kan dalk juis die onvaste vertrekpunt wees wat die derde paradigma kenmerk. Wanneer die teologiese wetenskap egter besin oor 'n "ewige, onbegryplike, onsienlike, onveranderlike, oneindige, almagtige en geestelike wese wat ons God noem" (NGB, art. 1), dan is 'n vertrekpunt wat spreek van nederigheid en nie-fmaliteit dalk heel gepas.

\section{Slot}

Indien die gilde van Bybelwetenskaplikes in Suid-Afrika erns maak met die ontwikkelinge in filosofiese hermeneutiek (en dus nie die weg van Barth volg nie - hy bots juis met Bultmann in hierdie opsig), sal daar gekyk moet word na resente bydraes soos diè van Gadamer in hierdie verband. Die aandeel van die interpreteerder in die betekenisgebeure en die konsekwensies daarvan vir die Bybelwetenskappe sal bestudeer en uitgelig en gedebatteer moet word. 'n Weg sal gevind moet word waarlangs subjektiwiteit nie vasval in totale relatiwisme nie (en antwoorde in hierdie verband is reeds aan die hand gedoen - Fish verwys byvoorbeeld na die rol van die kritiese gemeenskap) ${ }^{28}$

26 Daar is al daciop gewys dat Le Roux en Prinsloo as twee belangrike stemme binne dic SuidAfrikaanse Bybelwetenskap in wese saamstem dat daar nie iets soos die objektiewe verklaring van 'n teks bestaan nie (vgl. Van Deventer, 1998 92)

27 Die meer onlangse werk van Le Roux (1998) dul egter beslis in hierdie rigting.

28 Volgens PMB (1995:30) het Fish in sy vroeere werke gemeen dat dre teks aan die leser sy/ haar lesing voorskryf. In latere werke huldig Fish 'n teenoorgestelde standpunt, naamlik da die leser altyd die betekenis in 'n teks konstrucer. Tog ruil Fish nie bloot 'n kontroleerbare invloed van die teks op die leser in vir 'n onkontroleerbare invloed van die leser op die teks nie. Die subjektiwiteit van die individuele leser word aan bande gelê deur die invloed wat die 
Hierdie voorstel sou noodwendig konsekwensies vir kerklike leerstukke en selfs Skrifbeskouing inhou. Hierdie sake sal opnuut, met die oog op voortgaande reformasie, onder die loep geneem moet word. Indien daar egter gemeen word dat hierdie voorstel 'n "gevaar" vir die kerk (geloof?) inhou en dat hierdie sake eerder nie binne die teologiese debat moet figureer nie, geld 'n opmerking van Palmer (1969:95): "[p]erhaps it may be asserted that we today should interpret without trying to know what interpretation is, but this merely claims the right to do something without really knowing what is being done". En waar 'n mens besig is met die interpretasie van 'n teks wat so 'n sentrale plek in die lewens van soveel mense inneem, dan moet jy sekerlik weet wat jy doen.

\section{Bibliografie}

BARTON, J 1996. Reading the Old Testament. Method in Biblical study Revised and enlarged edition. Louisville : Westminster John Knox Press

BIBLE AND CULTURE COLLECTIVE, THE 1995. The postmodern Bible. New Haven : Yale

CLINES, D I.A 1993. A world established on water (Psalm 24): Reader-response, deconstruction and bespoke interpretation (In Exum, J.C. \& Clines, D.J.A., eds The new literary criticism and the Hebrew Bible. Journal for the Study of the Old Testament. Supplement Series 143. Sheffield : JSOT Press. p 79-90.)

CLINES, D J A \& EXUM, J.C. 1993. The new literary criticism. (In Exum, J.C \& Clines, D.J.A., eds. The new literary criticism and the Hebrew Bible. Journal for the Study of the Old Testament Supplement Series 143 Sheffield : JSOT Press. p. 11-25)

COETZEE, J.C. 1988 Gedagtestruktuurontleding en die eksegese van die Heilige Skrifte. (In Coetzee, J.C., red Koninkryk, Gees en Woord. Pretoria : NG Kerkboekhandel. p 19-37.)

DEIST, F.E. 1984. 'n Kritiese evaluering van die kritiek van F.N. Lion-Cachet In die Skriflig, $18(4): 47-56$

DEIST, F.E. 1987. Om 'n geskiedenis van Israel te skryf (In Deist, F.E. \& Le Roux, J.H., reds Rewolusie en reinterpretatsie. LOT 4 Kaapstad. Tafelberg p. 31-45.)

DEIST, F.E. 1988. Naiewe realisme en Ou-Testamentiese wetenskap in die Nederduitse Gereformeerde Kerk (In Prinsloo, W.S. \& Vosloo, W., reds. In mensetaal oor God se Woord. Huldigingsbundel opgedra aan professor A H. van Zyl. Kaapstad : Lux Verbi. p 23-32.)

DEIST, F.E. 1994a Ervaring, rede en metode in Skrifuitleg 'n Wetenskapshistoriese ondersoek na Skrifuitleg in die Ned Geref. Kerk 1840-1990 Pretoria : RGN.

DEIST, FE. 1994b. Onlangse konsepte in teksuitleg en hulle konsekwensies vir die (gereformeerde) teologie In die Skriflig, 28(2): 165-178

DEIST, F.E. \& BURDEN, J.J. 1985. 'n ABC van Bybeluitleg Pretoria : Van Schaik.

DILTHEY, W 1989. Selected works. Volume 1. Introduction to the human sciences. (Edited, with an introduction, by R A Makkreel \& F. Rodi.) Princeton : Princeton University Press.

DOBBS-ALLSOPP, F.W. 1999 Rethinking historical criticism. Biblical Interpretation, $7(3)$ 235-271

DU TOIT, T 1998 Is dit die einde van die teologie? (Resensie van Spangenberg, Izak Perspektiewe op die Bybel Pretoria : Van Schaik) Insig: 30, Junie

kritiese gemeenskap waaruit die leser kom, op hom/haar uitoefen (vgl ook Fowler [1992:385386] se bespreking van Fish) 
EXUM, J.C 1993. Who's afraid of the "endangered ancestress"? (In Exum, J.C. \& Clines, D J.A., eds The new literary criticism and the Hebrew Bible Journal for the Study of the Old Testament. Supplement Series 143 Sheffield : JSOT Press p. 91-113.)

FOWLER, R M. 1992 Who is "the reader" in reader response criticism? (In House, P R, ed Beyond form criticism Essays in Old Testament literary criticism Winona Lake Eisenbrauns p 376-394)

GADAMER, H-G 1975 Truth and method London : Sheed \& Ward

HELBERG, J L 1983. Verklaring en prediking van die Ou Testament Potchefstroom Potchefstroomse Teologiese Publikasies

HIERONYMUS 1958. Commentary on Daniel (Translated by G.L Archer) Grand Rapids Baker

JEANROND, W.G 1996 Hermeneutics (/n Coggins, R J. \& Houlden, J L., eds A dictionary of Biblical interpretation pp 282-284)

KAISER, W.C. 1981. Towards an exegetical theology Biblical exegesis for preaching and teaching. Grand Rapids : Baker

KAISER, W C \& SILVA, M. 1994. An introduction to Biblical hermeneutics. Grand Rapids Zondervan

KENYON, K M 1978. The Bible and resent archaeology London. Colonnade.

KROEZE, J.H. 1963 Studies on the Psalms Papers read at the 6th meeting of die OT. Werkgemeenskap in Suid-Afrika. Potchefstroom : Pro Rege.

LATEGAN, B.C. 1984. Current issues in the hermeneutical debate. Neotestamentica, 18:1-17,

LE ROUX, J H. 1993. A story of two ways. Thirty years of Old Testament scholarship in South Africa Pretoria : Verba Vitae

LE ROUX, J H. 1996 Eksegese is 'n spel Acta Theologıca, 16(1) 41-56

LE ROUX, JH 1998. Israel's past and the feeling of loss (Or: Deconstructing the "minimum" of the "minimalists" even further). Old Testament Essays, 11(3) 477-486

LINGE, DE 1976 Editor's introduction. (In Gadamer, H-G. Philosophical hermeneutics Translated and edited by David E. Linge Berkeley : University of California Press. p xiIviii.)

LION-CACHET, F N 1984. 'n Kritiese beskouing van Deist se "ABC van Bybeluitleg" In die Skriflig, 18(1) 38-51.

LION-CACHET, F.N. 1989, So het dit begin Gods boodskap in die raamwerk van die historiese boeke van die Ou Testament. Potchefstroom : Dept. Sentrale Publikasies

LOADER, J A. 1994 Die weg van die Here in die woestyn oftewel God se grootpad in die wildernis: Oor A Story of Two Ways Skrifen Kerk, 15(2) 391-413.

LOWTH, R 1969. Lectures on the sacred poetry of the Hebrews. (Translated by G. Gregory.) New York : Garland

LUNDIN, R 1991 Hermeneutics (In Walhout, C \& Ryken, L., eds. Contemporary literary theory. A Christian appraisal Grand Rapids: Eerdsmans p 149-171)

MARALDO, JC 1974 Der Hermeneutische Zirkel Untersuchungen zu Schleiermacher, Dilthey und Heidegger. Munchen : Karl Alber Verlag.

McCARTNEY, D \& CLAYTON, C 1994 Let the reader understand A guide to interpreting and applying the Bible Wheaton: Victor Books

MEIJER, J G 1998 Hou vas wat jy het. Reaksie op "Twee strome"-artikels (2) Skrifgeloof Die Kerkblad, 10 l(3046) 24-25

MILBANK, J 1994. Theology and social theory Beyond secular reason Oxford : Blackwell

NATIONS A L. 1983 Historical criticism and the current methodological crisis. Scotrish Joumal of Theology, 36(1) 59-71

PALMER, RE. 1969. Hermeneutics. Interpretation theory in Schleiermacher, Dilthey, Heidegger, and Gadamer. Evanston : Northwestem University Press 
H.J.M. (Hans) van Deventer

POSTMODERN BIBLE

$k y k$ BIBLE AND CULTURE COLLECTIVE

PRINSLOO, W.S. 1977

$k y k$ VAN ZYL A H et al. 1977

PRINSLOO W.S. 1996. Eksegese is 'n spel (sonder reels?) Acta Theologica, 16(2):21-33

PUNT, J. 1998 New Testament interpretation, interpretive interests, and ideology: methodological deficits amidst SA methodolomania. Scriptura, 65:123-152

SAHAKIAN, W.S 1968. History of Philosophy. New York : Barnes \& Noble

SCHLEIERMACHER, F.D.E. 1986. Hermeneutics: The handwritten manuscripts. (Edited by Heinz Kimmerle. Translated by James Duke and Jack Forstman) Atlanta : Scholars Press.

SCHULZE, L.F. 1980. Calvyn en die Skrifgesag. In die Skrifig, 14(56) 27-39

SCHULZE, L.F. 1998a. Mag ons die Bybel interpreteer? Die Kerkblad, 101(3044):14-15

SCHULZE, L F. 1998b. 'n Belangrike onderskeiding Die Kerkblad, 101(3050) 23-24

SLLVA, M

$k y k$ KAISER, W C. \& SILVA, M.

SNYMAN, G 1992a. Kenteoretiese besinning oor teologiebeoefening aan die Teologiese Skool Potchefstroom die afgelope twintig jaar. In die Skriflig, 26(2):247-266.

SNYMAN, G $1992 \mathrm{~b}$ Binnegevegte in die GKSA: verskuiwing van "plausibility structures"? In die Skriflig, 26(3):351-367.

SPANGENBERG, I.J.J. 1994. Paradigmaveranderinge in die Bybelwetenskappe 'n Bydrae tot die gesprek tussen die Bybelwetenskappe en Sistematiese Teologie. Religie \& Teologie, 1(2): 144-184

SPANGENBERG, Izak. 1998a. Perspektiewe op die Bybel. God se woord in mensetaal Pretoria : Van Schaik

SPANGENBERG, I J.J. 1998b Op pad na 2000 - oftewel, oor al die dinge wat gebeur het Old Testament Essays, 11(3):534-566.

THISELTON, A.C. 1986. The New Hermeneutic. (In McKim, D.K., ed. A guide to contemporary hermeneutics. Grand Rapids : Eerdmans. p 78-107)

THISELTON, A.C. 1992. New horizons in hermeneutics The theory and practice of transforming biblical reading. Grand Rapids : Zondervan.

TUCKER, G.M. 1971. Form criticism of the Old Testament. Minneapolis : Fortress Press

VAN AARDE, A.G. 1981. Die kritiek op die fundamentalisme: 'n vorm van teologiese liberalisme? Hervormde Teologiese Studies, 37(4):6-21.

VAN DEVENTER, H.J.M. 1998. Oor paaie, sirkels en waarhede 'n Bydrae met betrekking tot die huidige hermeneutiese gesprek. Acta Theologica, 18(1):77-95

VAN ROOY, H.F. 1995. Die bydrae en relevansie van die Ou-Testamentiese wetenskapsbeoefening in die Gereformeerde Kerke in Suid-Afrika (1869-1994). In die Skriflig, 29(1\&2):47-76

VAN ZYL, A.H., EYBERS, I.H., LE ROUX, J H., PRINSLOO, W.S., SWANEPOEL, F.A. \& VOSLOO, W. 1977. Israel en sy bure. Durban : Butterworths.

VEESER, H.A. 1994. The new historicism. (In Veeser, H.A, ed. The new historism reader New York : Routledge. p. 1-32.)

VERGEER, W. 1993. Teologie en kenteorie. 'n Reaksie op die artikels van Gerrie Snyman. In die Skriflig, 27(4):563-582.

VERGEER, W. 1998. Professor, ek verstaan nie ... Die Kerkblad, 101(3050):22-23

WEINSHEIMER, J.C. 1985. Gadamer's hermeneutics. A reading of Truth and Method. New Haven: Yale University Press

WOLTERSTORFF, N. 1984. Reason within the bounds of religion. Grand Rapids Eerdmans. 